\title{
Core Competency of Mid-level Public Health Managers in Bangladesh
}

\author{
Jahan $\mathrm{S}^{1}$, Flora $\mathrm{MS}^{2}$ \\ ${ }^{1}$ Dhaka National Medical College, Dhaka, Bangladesh \\ ${ }_{2}^{2}$ Institute of Epidemiology, Disease Control and Research (IEDCR), Dhaka, Bangladesh \\ e-mail: sharminjahan1@yahoo.com
}

\begin{abstract}
Bangladesh has been making remarkable progress in health sector. Despite, there are some areas where further intervention is required. People-centered health systems cannot be strengthened without competent management. Core competencies are the essential knowledge, skills and attitudes required for the practice of public health. This was a first kind of effort to assess the core competencies of mid-level public health managers, working at different tiers of health system in Bangladesh. This descriptive cross-sectional study was conducted from July 2012 to June 2013, to assess the core competencies of mid-level public health managers including Civil Surgeons, Programme Managers, Upazilla Health and Family Planning Officers and Upazilla Family Planning Officers. Data were collected by pretested self administered questionnaire based on competency measuring scale consisting of four grades of scoring. The questionnaires were mailed to 678 managers of whom $26 \%$ responded. The male female ratio of the respondents was 8:1 with an average age of 51 years. The level of competency was found, on scale, between aware and knowledgeable. Only $12.4 \%$ of the managers had postgraduate education in public health and they obtained higher average scores in all domains. The overall scores of managers in analytical, policy development, communication, cultural competency, community dimension of practice, public health science, financial planning and leadership skills were 2.6, 2.5, 2.6, 2.6, 2.7, 2.3, 2.6 and 2.7 respectively. Some two-thirds (65.7\%) of the respondents had short training on different public health areas, and they showed better competency. The study findings suggest that there are scopes of improvement in the competency of mid-level public health managers in Bangladesh. As postgraduation and short training in public health might improve the competency level of the midlevel managers, so education and training for them are thus recommended.
\end{abstract}

Keywords: Competency, Public health managers, Mid-level.

\section{Introduction}

Millions of people still die every year from preventable causes, no matter how much money the country puts into improving health services, health systems, educational campaigns, health worker training, equipment, and facilities. Medically, it is known what to do to save these lives and significantly reduce illness. Scaling up these high-impact interventions and proven best practices is the key to preventing avoidable deaths and achieving major improvements in health. Scale-up is also essential to get on track to meet the Sustainable Development Goals (SDGs) for health. However, scale-up does not happen without inspired leadership and skilled management.
SDGs target to end the epidemics of tuberculosis by $2030 .{ }^{1}$ The prevalence of tuberculosis increased from 391 per 100,000 populations in 2007 to 411 per 100,000 populations in 2013. ${ }^{2}$ Immunization survey observed $97.8 \%$ coverage BCG vaccine while full vaccinated children is $78 \%$ indicating a significant amount of dropout. Likewise, current contraceptive prevalence rate (CPR) is 62 . The targeted CPR is $80 \%$, which should be reached within the year $2020 .{ }^{3}$ It can be said that Bangladesh is away from reaching the target regarding contraception. Therefore, the question arises, why are the public health programmes not performing as expected? This question raises another important question: are the public health managers in Bangladesh competent 
enough to perform their job? So far reviewed, there was no study done on competency of public health managers in Bangladesh. The current study was done for assessing the level of core competency of mid-level public health managers in Bangladesh.

\section{Materials and Methods}

This was a descriptive cross-sectional study done over a period of one year from July 2012. The health managers responsible for mid level public health management were the study population. All Civil Surgeons (64), 372 Upazilla Health and Family Planning Officers (UHFPO), 221 Upazilla Family Planning Officers (UFPO) and 21 Programme Managers (PM) and Deputy Programme Managers (DPM) of different government programmes and nongovernment organizations were mailed a structured questionnaire. The questionnaire included questions based on competency measuring scale developed by Janet Place, North Carolina Public Health Academy under University of North Carolina and modified by Public Health Foundation. ${ }^{4}$ The scale comprises eight domains. Seventy-six competencies (indicators) under those domains cumulate the "core competencies". The score obtained by the respondents were summed up and average score was calculated in each domain. The level of proficiency was scored 1 for "none", 2 for "aware", 3 for "knowledgeable" and 4 for "proficient". Scale "none" is for if the respondent feel a need for improvement or 4 if $\mathrm{s} / \mathrm{he}$ thinks that is excelling at that competency. Respondents were reminded by phone calls and e-mails several times. The overall response rate was 178/678 (26\%). Finally responses of 13 Civil Surgeons, 14 PM and DPM, 113 UHFPO and 38 UFPO were included in the analysis. Descriptive statistics, independent sample t test and correlations were done. Ethical approval was obtained from the Ethical Review Committee of the National Institute of Preventive and Social Medicine (NIPSOM), Dhaka.

\section{Results}

About two-thirds of the respondents $(63.5 \%)$ were UHFPO, and about one-fifth $(20.2 \%)$ were UFPO. The male female ratio was almost 8:1. The age ranged from 25 to 62 years. The mean age of the respondents was 51 years with SD of 7.3 years. Majority of the respondents $(83.7 \%)$ were $\geq 45$ years. Except a few (11), all respondents had been working in government organizations. Out of all mid-level managers, only $12.4 \%$ had post-graduation in public health.

The highest overall score was found in community dimension of practice (2.7); and leadership and systems thinking skills (2.7). Whereas, the lowest mean score was in public health science skills (2.3). In each domain overall score was between "aware" and "knowledgeable" and male managers obtained, on an average, higher score than their female counterparts (figure 1).

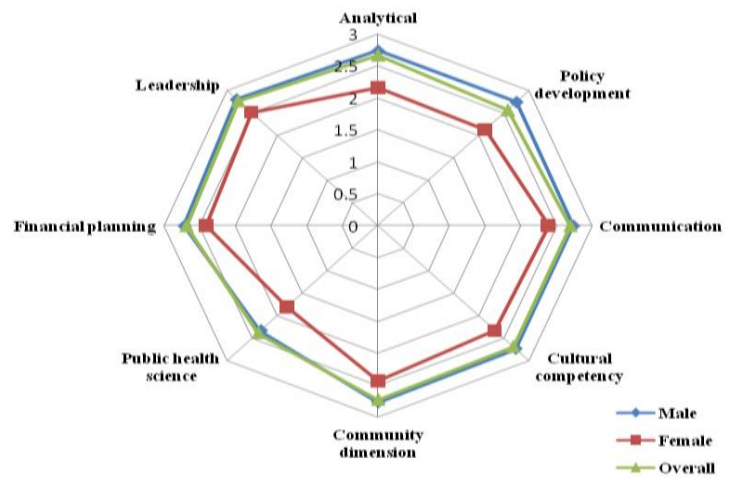

Figure 1: Distribution of competency scores

The postgraduate public health managers had the higher average scores in all domains than the non post-graduate managers (figure 2 ).

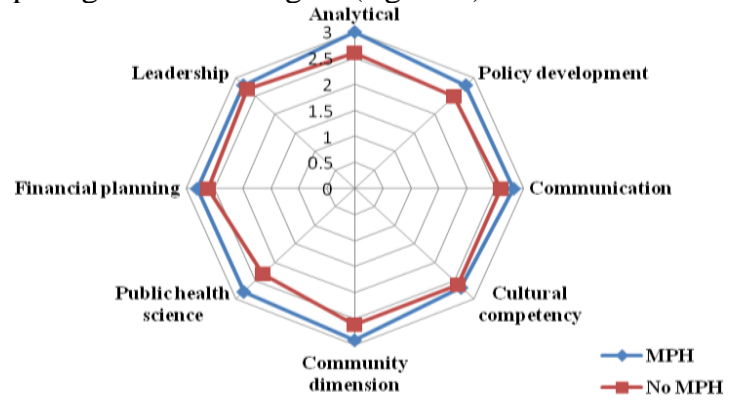

Figure 2: Distribution of the competency scores by postgraduation 
The Civil Surgeons had the highest average scores in each domain of core competency although the findings were based on a limited sample. The leadership and community dimension of practice skills had competency scores of "knowledgeable". It was found that UFPO had the lowest scores in maximum domains (figure 3 ).

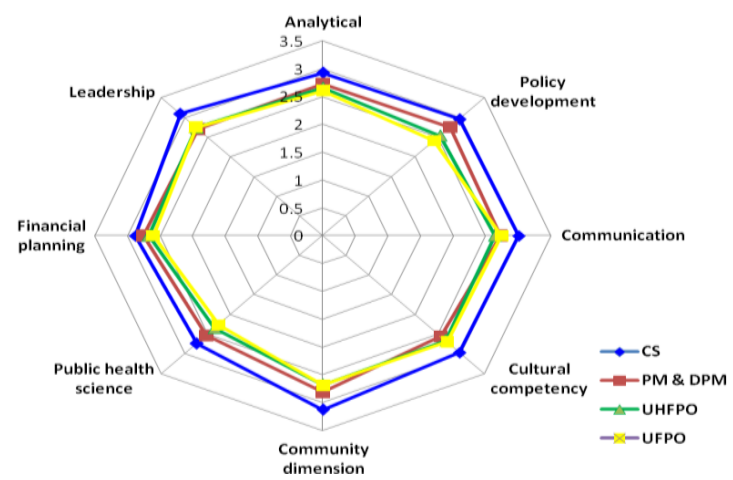

Figure 3: Radar chart showing the average scores of skills of public health managers

Some two-thirds $(65.7 \%)$ of the public health managers received short training on different public health issues which did not directly focus every domain of competency measuring scale. The managers got training on topics related to analytical, communication, community dimension of practice, public health science, financial planning and management; and leadership and system thinking domain. Majority $(61.8 \%)$ of the managers received training on community dimension of practice skills. No training was observed in the policy development and cultural competency domain. The study findings showed significant difference in competency score between trained and non-trained public health managers (table I).

Table I: Effect of training in public health on competency measuring scales

\begin{tabular}{|c|c|c|c|c|}
\hline \multirow{2}{*}{ Domains } & \multirow{2}{*}{$\begin{array}{c}\text { Managers } \\
\text { received } \\
\text { training } \\
\text { (Percentage) }\end{array}$} & \multicolumn{2}{|c|}{$\begin{array}{c}\text { Average } \\
\text { competency score }\end{array}$} & \multirow{2}{*}{$\begin{array}{c}p \\
\text { value }\end{array}$} \\
\hline & & $\begin{array}{c}\text { Trained } \\
\text { managers }\end{array}$ & $\begin{array}{c}\text { Non-trained } \\
\text { manage-rs }\end{array}$ & \\
\hline $\begin{array}{l}\text { Analytic/Assessmen } \\
\text { t skills }\end{array}$ & 27.0 & 2.9 & 2.6 & 0.07 \\
\hline $\begin{array}{l}\text { Communication } \\
\text { skills }\end{array}$ & 24.7 & 2.9 & 2.6 & 0.00 \\
\hline $\begin{array}{l}\text { Community } \\
\text { Dimensions of } \\
\text { Practice skills }\end{array}$ & 61.8 & 2.8 & 2.6 & 0.18 \\
\hline $\begin{array}{l}\text { Public Health } \\
\text { Sciences skills }\end{array}$ & 18.0 & 2.4 & 2.3 & 0.79 \\
\hline $\begin{array}{l}\text { Financial Planning } \\
\text { and Management } \\
\text { skills }\end{array}$ & 33.1 & 2.9 & 2.6 & 0.00 \\
\hline $\begin{array}{l}\text { Leadership and } \\
\text { Systems Thinking } \\
\text { skills }\end{array}$ & 46.1 & 2.9 & 2.6 & 0.00 \\
\hline
\end{tabular}

Public health work experience measured by duration of work in public health related position, on an average, was 12.8 years with the minimum of 1 month and maximum of 35 years. As duration of work in public health related position was not normally distributed, Spearman's rank-order correlation, a non parametric test, was undertaken between skills and duration of work in public health related position. A positive relationship was noted between these two variables (table II).

Table II: Distribution of the respondents showing relation of skills with their service

\begin{tabular}{lcc}
\hline \multicolumn{1}{c}{ Skills } & $\begin{array}{c}\text { Duration of work in public health } \\
\text { Correlation } \\
\text { coefficient [r] }\end{array}$ & $\boldsymbol{p}$ value \\
\hline Analytic/assessment & 0.246 & 0.001 \\
Policy development & 0.223 & 0.003 \\
$\begin{array}{l}\text { Communication } \\
\text { Cultural competency }\end{array}$ & 0.210 & 0.005 \\
Community dimensions of & 0.223 & 0.003 \\
practice & 0.248 & 0.001 \\
$\begin{array}{l}\text { Public health sciences } \\
\text { Financial planning and }\end{array}$ & 0.246 & 0.001 \\
management & 0.248 & 0.001 \\
$\begin{array}{l}\text { Leadership and systems } \\
\text { thinking }\end{array}$ & 0.235 & 0.002 \\
\hline
\end{tabular}

\section{Discussion}

Only one-fourth of the managers responded to the mailed questionnaire, therefore, might not reflect the actual situation. Listing of mid-level managers showed very limited women participation in the public health management. The response rate was higher in female (19/41) than male (159/637) managers.

The level of competency of mid-level public health managers were between "aware" to "knowledgeable". But, Nuntavarm VichitVadakan expected the average score of competency should be at least between "knowledgeable" to "proficient" in all dimensions. ${ }^{5}$

The highest overall score (2.7) was found in both leadership and systems thinking skill, and community dimension of practice skills. In both the areas the managers were trained through short training. Training showed higher scores and significant impact on their competencies (table 1). These trainings are mostly in-service training programmes and very much job oriented. Training on specific domains can surely enhance the competency level amongst 
the public health managers. A study done by American Public Health Association in 2001, also found that four out of five public health workers lacked formal public health training. ${ }^{6}$ Despite the need, there are few training opportunities for the existing public health workforce.

The lowest score (2.3) obtained by the managers was in public health science skill domain. Improvement in public health science skills requires formal training such as post-graduation or long term training. The current sample included only $12 \%$ public health postgraduates. Another domain which requires public health post-graduation is the analytical domain. In both the domains the managers having Masters in Public Health obtained marked higher scores than their non-postgraduate colleagues. The postgraduate public health professionals showed better competency in all domains in this study. Like Bangladesh, similar picture was depicted in a study in Texas. ${ }^{7}$ They found that only $7 \%$ of public health workers had formal education in public health.

\section{Conclusion}

The study included only a few female managers who showed poorer competency; therefore, females need to be empowered and encouraged to work at these position. The managers having public health postgraduation had better knowledge in all domains but only a tenth of them did. Postgraduation in public health might be considered as a prerequisite for the public health managers.

Acknowledgements: Authors acknowledge the financial grant of BMRC for this study. We would like to extend sincere thanks to the respected participants.

\section{Reference}

1. Bangladesh Planning Commission. MDGs to Sustainable Development Transforming our World: SDG Agenda for Global Action (2015-2030). A brief for Bangladesh delegation: UNGA $70^{\text {th }}$ Session, 2015. General Economics Division. Government of People's Republic of Bangladesh. September, 2015.

2. Bangladesh Planning Commission. The Millennium Development Goals, Bangladesh Progress Report 2012. General Economics Division. Government of People's Republic of Bangladesh, Dhaka, 2013.

3. National Institute of Population Research and Training (NIPORT), Mitra and Associates, and ICF International. Bangladesh Demographic and Health Survey 2011. Dhaka, Bangladesh. 2013.

4. Place J. North Carolina Public Health Academy. Council on Linkage Between Academia and Public Health Practice. 2010; Available at: www.phf.org

5. Vichit-Vadakan N, Chuchat A, Love EJ. Assessing the required skill mastery in public health competencies in Thailand. Education for health: 2006; 19: 233-43. Available at: http://www.tandf .co.uk/journals.

6. American Public Health Association. The affordable care act's public health workforce provisions: Opportunities and challenges. Center for Public Health Policy. Issue brief June 2011. Washington, DC. Available at: www.apha.org

7. Marcus A.B., Keith W.C., Catherine R.S., Marjorie A.C. Complementary competencies: public health and health sciences librarianship, Journal of the Medical Library Association. 2005; 93: 338-47. Available at: www.ncbi.nlm.nih.gov. 